\title{
Coal washing scenario in India and future prospects
}

\author{
R. Venugopal ${ }^{1} \cdot$ J. P. Patel $^{2} \cdot$ C. Bhar $^{3}$
}

Received: 9 November 2015/Revised: 22 April 2016/Accepted: 7 June 2016/Published online: 28 June 2016

(C) The Author(s) 2016. This article is published with open access at Springerlink.com

\begin{abstract}
Coal Washing Exploration in India dates back to 1900s; though, first coking coal washeries in India were installed after independence. At present, most of the coking coal washeries are owned by Public Sector Companies; whereas, most of the non-coking coal washeries are owned by Private Sector. Even after six decades of coal washing practices, there has not been significant development in the coal washing intelligentsia. Indian Coal Washing industry is still dependent on imported equipment, which has been designed to treat coal that is significantly different from Indian coal of drift origin. In this paper, authors have ventured into evolution of Indian Coal Washing Industry (with a focus on coking coal washing sector), its present condition and future prospect for growth. The paper emphasizes need for developing indigenous solutions to industrial challenges and highlights importance of increased coordination among academia-research institutions and coal industry.
\end{abstract}

Keywords Coking coal washing $\cdot$ Indian coal industry $\cdot$ History of coal washing $\cdot$ Future prospects

\section{Evolution of coal washing in India}

After setting up Steel Plants in India (in 1907), Tata Iron and Steel Company (TISCO) started explorations to meet the demand of coking coal for their steel plants; and, first breakthrough was achieved by Mr. A. Farquhar during his washability studies of Jharia and Raniganj coal during 1918-1926. After ascertaining economic viability, in 1946, TISCO decided to set up Coal Washeries in West Bokaro (1951) and Jamadoba (1952) (Ghosh 1964; Sen 2015). Chance Cone separator (a dense media separator utilizing sand as media) was the first washing equipment installed in

\section{R. Venugopal}

vrayasam@yahoo.com

1 Dept. of Fuel and Mineral Engineering, Indian School of Mines, Dhanbad, Jharkhand 826004, India

2 Washery Division, Bharat Coking Coal Limited, Saraidhela, Dhanbad, Jharkhand 828127, India

3 Dept. of Management Studies, Indian School of Mines, Dhanbad, Jharkhand 826004, India
Jamadoba Coal Preparation Plant (JCPP) for treatment of Jamadoba and Bhowra Coal. Subsequently, Lodna Coal Company set up Feldspar Jig-based very simple Coal Washery in 1955. (Ghosh 1964; Sen 2015; Singh and Guha 1965; Sinha 1988).

Hindustan Steel Limited (HSL) was set up in 1954, for expansion of Steel Industry in India. Similarly, National Coal Development Corporation (NCDC) was founded for planned growth of coal mining industry in India. To meet demand of coking coal for HSL Steel Plants, Central Coal Washeries in the vicinity of existing Marshaling yards of Kargali, Durgapur, Dugda, Bhojudih and Patherdih were envisaged; and Kargali Washery was commissioned in 1958 by NCDC as first public sector washery in India. Subsequently, Durgapur, Dugda, Bhojudih and Patherdih Coking Coal Washeries were commissioned during the III and IV Five Year Plans. (CCL 2015; CIL 2015; Ghosh 1964; CCL 2015; AICC 1965; Singh and Guha 1965; Sarkar 1972; Das 1975; Agrawal 1976; CEMPDIL 2016; Konar et al. 1998).

Following the footprints, Indian Iron and Steel Company (IISCO), also set up Chasnalla Washery in 1968 (Sarkar 
1972; Agrawal 1976; Konar et al. 1998; Rai and Tiwari 2009; Sen 2015). Later on, NCDC installed Kathara and Swang Washeries in 1969 and 1970. After nationalization of coal industry in India, ownership of NCDC Washeries was transferred to Central Coalfields Limited (CCL), (CEMPDIL 2016).

After a decade, for administrative reasons, ownership of SAIL Washeries was transferred to Bharat Coking Coal Limited (BCCL). To cater for the growing demand of clean coal, Coal India commissioned seven more coking coal Washeries (Sudamdih, Moonidih, Nandan, Barora, Mohuda, Kedla and Madhuband) during 1980-2000 (Ministry of Coal 2014; Sen 2015; Sinha 1988; Saxena 2015; NSO 2015). The most recent ones are Kedla and Madhuband Washeries of CCL and BCCL commissioned in 1997 and 1998 respectively.

Over the period, quality of coal has deteriorated due to exhaustion of superior grade coal in upper seams of BCCL and CCL Coal Belt (Sarkar et al. 2015). However, there has not been significant development in coal washing circuits, as the most recent washeries (Kedla and Madhuband) are Batac Jig-based washeries in contrast with the earliest coal washeries of HSL, which comprised of Heavy Media Separators (Rai and Tiwari 2009).

The demand of coal increased with the growth of Steel Industry. Keeping this in view, Coal India has planned to install six new coking coal washeries in BCCL with design capacity of 18.6 MTPY. These washeries will be installed and run on BOM scheme (Build Operate and Maintain). Three of these washeries are under construction. Five stage of Washing is being introduced in India with these washeries (Sarkar et al. 2015; Saxena 2015).

\section{Growing importance of washing}

India has proven coal reserves of total 125.91 billion tons, out of which only 18.4 billion tons is that of coking coal as shown in Table 1 (Source: Ministry of Coal).

Over the years, prime-coking coal reserves in the Jharia Coal Field have been exploited from the upper seams, leaving behind lower seams of inferior grade coal for further extraction.

Grade wise distribution of various seams of coal in BCCL (the only producer of prime-coking coal in India) is indicated in Table 2 (Sarkar et al. 2015).

Unlike metallurgical grade coal (ST-I \& ST-II), inferior grade coal cannot be directly blended with imported coal for coke making. Increasing demand of growing steel industry and diminishing production of metallurgical grade coal has resulted in increasing import burden on Indian Steel Industry to meet its demand for quality coking coal (Ministry of Coal 2014; CIL 2015). Trend of gross national demand for coking coal, domestic production and import during last six years has been shown in Fig. 1 (Ministry of Coal 2014; NSO 2015).

Statistically, domestic production is enough to meet demand of coal for the Indian Steel Industry; still, import of coking coal has only been increasing. Inferior quality of Indian coking coal, and insufficient washing capacity are the principal reasons behind this huge demand-supply gap. Approx. $79 \%$ of the total national demand is met by imported coal. Quality of Coking Coal produced during 2014-2015 is indicated in Table 3. (Ministry of Coal 2014; NSO 2015).

It is evident that, about $95 \%$ of total coal produced in India is of Washery Grade -III and IV. As per Coal Statistic Report, only $24 \%$ of the total coking coal produced in India has been utilized in metallurgical sector; and remaining $76 \%$ has been diverted to non-metallurgical sector. The figures are even dismal, if only public sector companies are considered, with a meager $14.4 \%$ of the total coking coal utilization in metallurgical sector. The situation is alarmingly critical as we are not only losing valuable coking coal reserves to non-metallurgical sectors, it's costing Indian foreign currency reserves to the tune of US $\$ 5.2$ billion in import of coking coal (Ministry of Coal 2014; CIL 2015).

\section{Existing scenario of coking coal washing in India}

So far, 25 coking coal Washeries have been installed and commissioned in India out of which only 19 are in operation at present with a total washing capacity of 33.17 MTY; out of these Washeries, 15 are operating in Public Sector. (Sen 2015; Saxena 2015; NSO 2015 ; Konar et al. 1998; AICC 1965; Sinha 1988; Rai and Tiwari 2009). It is evident from Table 3 and Table 4 that the existing capacity of Washeries are not sufficient to handle total amount of coking coal produced in the country, and remaining quantity of coal is bound to get diverted to non-

Table 1 Geological reserves of coal in India as on 01.04.2014 (Quantity in MT)

\begin{tabular}{lrrrr}
\hline Type of coal & Proved & Indicated & Inferred & \multicolumn{1}{c}{ Total } \\
\hline (A) Coking & & & & \\
Prime coking & 4614 & 699 & 0 & 5313 \\
Medium coking & 13,303 & 11,867 & 1879 & 27,049 \\
Semi-coking & 482 & 1004 & 222 & 1708 \\
Sub-total coking & 18,400 & 13,569 & 2101 & 34,070 \\
(B) Non-coking & 106,916 & 128,838 & 30,249 & 266,002 \\
(C) Tertiary coal & 594 & 99 & 799 & 1493 \\
Total & 125,909 & 142,507 & 33,149 & 301,565 \\
\hline
\end{tabular}


Table 2 Grade wise distributions of coal seams/reserves in Bharat Coking Coal Limited

\begin{tabular}{llcl}
\hline Demarcation & Coal seam & Thickness (m) & Grade of coal \\
\hline Upper horizon & XVIII A/B/C/D & 5.9 & ST-II and W-I \\
& XVII & 4.45 & coking \\
& XVI A/B/C/D/E & 10.58 & \\
XV & 2.54 & W-I and W-II \\
& XIV & 0.56 & coking \\
& XIII & 3.94 & \\
XII & 6.25 & W-II coking \\
& XI/XII & 6.83 & \\
& IX/X, X & 10.57 & \\
Lower horizon & VIII A,B & 7.84 & NLW \\
& VIII & 2.62 & W-IV \\
& V/VI/VII & 20.84 & \\
& IV/(T)/IV (B) & 8.4 & Non-coking \\
\hline
\end{tabular}

metallurgical sector. Moreover, it is also to be noted that only 13.79 MT of Coking Coal is being channelized to Metallurgical Sector, which amounts to only $41.6 \%$ of the total washing capacity (Ministry of Coal 2014). This poor capacity utilization can be attributed to old plant machinery and obsolete washing circuit in most of the existing washeries, which have outlived their-designed life. Recurring losses in the coking coal washeries is another principal deterrent in capacity utilization (Sarkar et al. 2015). On further investigation, it was revealed that these washeries are operating at very poor yield; and in many of the public sector washeries fine coal circuit is not in operation (Sarkar et al. 2015; Alam and Patel 2012). Thus, actual utilization of coking coal in the metallurgical sector is even less, not more than $10.0 \%$. The authors are carrying out studies on Coking Coal Washeries of Bharat Coking Coal Limited to help improve their performance and ultimately maximize the optimum utilization of coking coal in the metallurgical sector.

Coal Washing Technology has evolved globally. Some countries have almost frozen their washing technology for a particular coal seam. This is not the case with Indian coal industry. The Washing Technology developed elsewhere, have been slightly customized to face the challenges of difficult washing characteristics of Indian Coal. As such, no washing equipment has been designed specifically to treat Indian Coal with difficult washing characteristics, which is not encountered in case of carboniferous coal. Details of washing schemes in existing coking coal washeries of India has been compiled in Table 4 (Sen 2015; Ministry of Coal 2014; Chakraborty et al. 2015; Sarkar et al. 2015; CCL 2012; Rai and Tiwari 2009). Heavy Media Cyclone is the most widely used separator in these washeries. Presence of high proportion of near-gravity-material (NGM) mandates cyclone washing (Rai and Tiwari 2009). Misplacement of coal in such washing schemes can be further improved with the aid of automation and control. However, most of the public sector washeries are yet to integrate automation and control in their existing circuits.

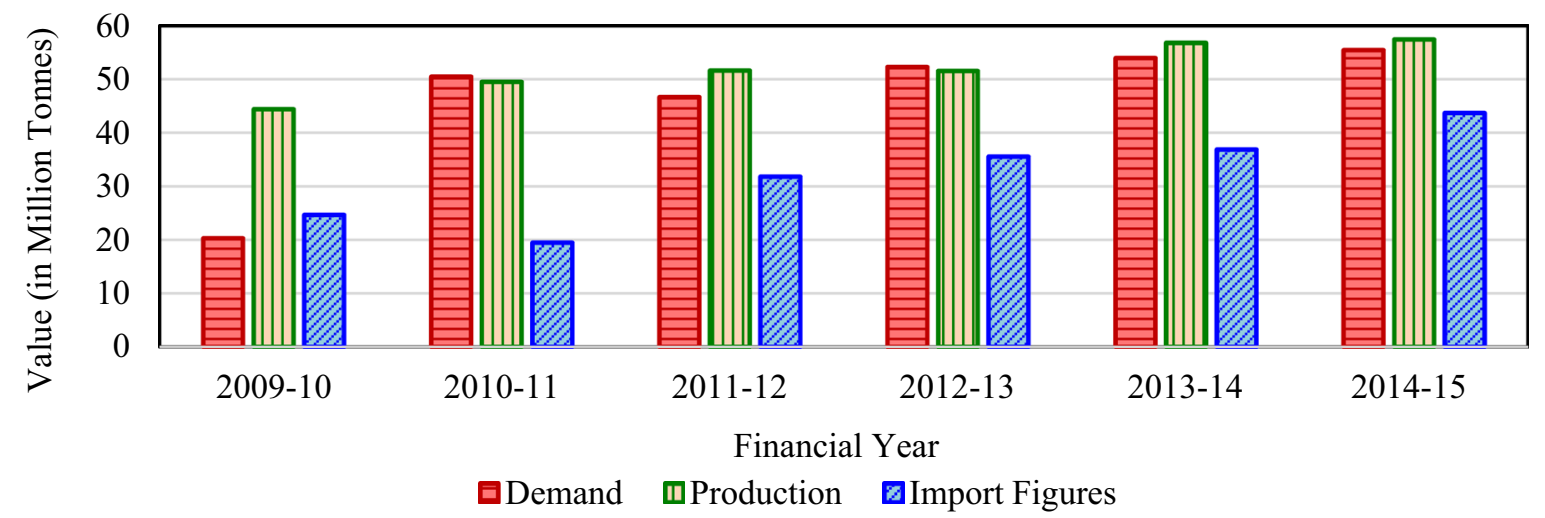

Fig. 1 Trend of gross national demand, annual production and import of coking coal in India

Table 3 Grade of coking coal produced in India

\begin{tabular}{lllllllr}
\hline Grade of coal & ST-I & ST-II & Semi coking & W-I & W-II & W-III & W-IV \\
\hline Production in MT & 0.50 & 0.456 & 0.13 & 0.115 & 2.228 & 12.499 & 41.973 \\
\hline
\end{tabular}


Table 4 Existing Coking Coal Washeries in India and Washing Technologies

\begin{tabular}{|c|c|c|c|c|c|c|}
\hline \multirow{2}{*}{$\begin{array}{l}\text { S. } \\
\text { no. }\end{array}$} & \multirow{2}{*}{$\begin{array}{l}\text { Name of } \\
\text { washery }\end{array}$} & \multirow{2}{*}{$\begin{array}{l}\text { Year of } \\
\text { commissioning }\end{array}$} & \multirow{2}{*}{$\begin{array}{l}\text { Design } \\
\text { capacity } \\
\text { (MTPY) }\end{array}$} & \multicolumn{3}{|c|}{ Washing technology } \\
\hline & & & & Coarse coal & Small coal & Fine coal \\
\hline 1 & Jamadoba & 1952 & 0.9 & - & $\begin{array}{l}-13+0.5 \mathrm{~mm} \\
(\mathrm{HM} \text { Cyclone })\end{array}$ & $\begin{array}{l}-0.5 \mathrm{~mm} \\
\text { (Flotation) }\end{array}$ \\
\hline 2 & Kargali & 1958 & 2.78 & $\begin{array}{l}-300+30 \mathrm{~mm} \\
(\text { Coarse Coal Jig) }\end{array}$ & - & - \\
\hline 3 & Durgapur $^{\mathrm{b}}$ & 1960 & 1.5 & $\begin{array}{l}-80+20 \mathrm{~mm} \\
(\mathrm{H} \mathrm{M} \text { Bath })\end{array}$ & $\begin{array}{l}-20+1.0 \mathrm{~mm} \\
(\text { Small Coal Jig })\end{array}$ & $\begin{array}{l}-1+0.25 \mathrm{~mm} \text { (Spiral) } \\
-0.25 \text { (Flotation) }\end{array}$ \\
\hline 4 & Bhojudih & 1962 & 1.7 & $\begin{array}{l}-75+25 \mathrm{~mm} \\
(\mathrm{HM} \text { Bath) }\end{array}$ & $\begin{array}{l}-25+0.5 \mathrm{~mm} \\
(\text { Batac Jig) }\end{array}$ & $\begin{array}{l}-0.5 \mathrm{~mm} \\
\left(\text { Flotation }^{\mathrm{a}}\right)\end{array}$ \\
\hline 5 & Dugda-II & 1968 & 1.8 & - & $\begin{array}{l}-13+0.5 \mathrm{~mm} \\
(\mathrm{HM} \text { Cyclone })\end{array}$ & $\begin{array}{l}-0.5 \mathrm{~mm} \\
\left(\text { Flotation }^{\mathrm{a}}\right)\end{array}$ \\
\hline 6 & DCOP & 1968 & 1.35 & Not Available & & \\
\hline 7 & Chasnalla & 1968 & 1.5 & $\begin{array}{l}-80+20 \mathrm{~mm} \\
(\mathrm{H} \mathrm{M} \text { Bath })\end{array}$ & $\begin{array}{l}-20+0.5 \mathrm{~mm} \\
(\text { Small Coal Jig) }\end{array}$ & $\begin{array}{l}-0.5+0.15 \mathrm{~mm}(\text { Spiral }) \\
-0.15(\text { Clean Coal })\end{array}$ \\
\hline 8 & Kathara & 1969 & 3.0 & $\begin{array}{l}-80+13 \mathrm{~mm} \\
\text { (Drewboy Bath) }\end{array}$ & $\begin{array}{l}-13+0.5 \mathrm{~mm} \\
(\mathrm{HM} \text { Cyclone })\end{array}$ & $\begin{array}{l}-0.5 \mathrm{~mm} \\
\left(\text { Flotation }^{\mathrm{a}}\right)\end{array}$ \\
\hline 9 & Swang & 1970 & 0.75 & $\begin{array}{l}-80+20 \mathrm{~mm} \\
(\text { Deshaler Jig) }\end{array}$ & $\begin{array}{l}-20+0.5 \mathrm{~mm} \\
(\mathrm{HM} \text { Cyclone })\end{array}$ & $\begin{array}{l}-0.5 \mathrm{~mm} \\
\left(\mathrm{WO} \mathrm{Cyclone}^{\mathrm{a}}\right)\end{array}$ \\
\hline 10 & Sudamdih & 1981 & 1.6 & - & $\begin{array}{l}-37+0.5 \mathrm{~mm} \\
(\mathrm{HM} \text { Cyclone })\end{array}$ & $\begin{array}{l}-0.5 \mathrm{~mm} \\
\left(\text { Flotation }^{\mathrm{a}}\right)\end{array}$ \\
\hline 11 & West Bokaro-II & 1982 & 1.8 & - & $\begin{array}{l}-13+0.5 \mathrm{~mm} \\
(\mathrm{HM} \text { Cyclone })\end{array}$ & $\begin{array}{l}-0.5 \mathrm{~mm} \\
\text { (Flotation) }\end{array}$ \\
\hline 12 & Moonidih & 1983 & 1.6 & - & $\begin{array}{l}-30+0.5 \mathrm{~mm} \\
(\mathrm{HM} \text { Cyclone })\end{array}$ & $\begin{array}{l}-0.5 \mathrm{~mm} \\
\left(\mathrm{WO} \mathrm{Cyclone}^{\mathrm{a}}\right)\end{array}$ \\
\hline 13 & Nandan & 1984 & 1.2 & $\begin{array}{l}-75+13 \mathrm{~mm} \\
(\text { Coarse Coal Jig) }\end{array}$ & $\begin{array}{l}-13+0.5 \mathrm{~mm} \\
\text { (Fine Coal Jig) }\end{array}$ & $\begin{array}{l}-0.5 \mathrm{~mm} \\
\left(\text { Flotation }^{\mathrm{a}}\right)\end{array}$ \\
\hline 14 & Rajrappa & 1988 & 3.0 & $\begin{array}{l}-80+16 \mathrm{~mm} \\
(\text { Batac Jig) }\end{array}$ & $\begin{array}{l}-16+0.5 \mathrm{~mm} \\
(\text { Fine Coal Jig) }\end{array}$ & $\begin{array}{l}-0.5 \mathrm{~mm} \\
\left(\text { Flotation }^{\mathrm{a}}\right)\end{array}$ \\
\hline 15 & Mohuda & 1990 & 0.63 & - & $\begin{array}{l}-25+0.5 \mathrm{~mm} \\
\text { (HM Cyclone) }\end{array}$ & $\begin{array}{l}-0.5 \mathrm{~mm} \\
\left(\text { Flotation }^{\mathrm{a}}\right)\end{array}$ \\
\hline 16 & Bhelatand & 1994 & 0.86 & - & $\begin{array}{l}-13+0.5 \mathrm{~mm} \\
(\mathrm{HM} \text { Cyclone })\end{array}$ & $\begin{array}{l}-0.5 \mathrm{~mm} \\
\text { (Flotation) }\end{array}$ \\
\hline 17 & West Bokaro-III & 1994 & 2.1 & - & $\begin{array}{l}-13+0.5 \mathrm{~mm} \\
(\mathrm{HM} \text { Cyclone })\end{array}$ & $\begin{array}{l}-0.5 \mathrm{~mm} \\
\text { (Flotation) }\end{array}$ \\
\hline 18 & Kedla & 1997 & 2.6 & $\begin{array}{l}-80+15 \mathrm{~mm} \\
(\text { Batac Jig) }\end{array}$ & $\begin{array}{l}-15+0.5 \mathrm{~mm} \\
\text { (Fine Coal Jig) }\end{array}$ & $\begin{array}{l}-0.5 \mathrm{~mm} \\
\left(\text { Flotation }^{\mathrm{a}}\right)\end{array}$ \\
\hline 19 & Madhuband & 1998 & 2.5 & - & $\begin{array}{l}-13+0.5 \mathrm{~mm} \\
(\text { Batac Jig) }\end{array}$ & $\begin{array}{l}-0.5 \mathrm{~mm} \\
\left(\text { Flotation }^{\mathrm{a}}\right)\end{array}$ \\
\hline
\end{tabular}

${ }^{a}$ Fine coal circuit is not in operation

${ }^{b}$ Details pertaining to operation of fine coal circuit not available

\section{Characteristic of Indian coal}

Indian coals of drift origin (Gondwana Coal) can be characterized by high ash content with impurities disseminated in the coal bed. Very thin bands $(5 \mathrm{~mm}-3 \mathrm{~cm})$ of impurities are often encountered in between coal bands. Such coal has high near gravity material (NGM $>30 \%$ ) content. Liberation size of coal is much smaller; and significant improvement in yield is observed when coal is crushed down to as low as $-6 \mathrm{~mm}$ to $-3 \mathrm{~mm}$ and $-1 \mathrm{~mm}$. 
Table 5 Upcoming coking coal washeries in coal India limited

\begin{tabular}{|c|c|c|c|c|}
\hline \multirow[t]{2}{*}{ Name of washery } & \multirow{2}{*}{$\begin{array}{l}\text { Design } \\
\text { capacity }\end{array}$} & \multicolumn{3}{|l|}{ Washing technology } \\
\hline & & Coarse coal & Small coal & Fine coal \\
\hline Madhuband & 5.0 MTY & $\begin{array}{l}-75+13 \mathrm{~mm} \\
\text { (Deshaling cyclone) }\end{array}$ & $\begin{array}{l}-13+1 \mathrm{~mm} \\
(\mathrm{HM} \text { Cyclone })\end{array}$ & $\begin{array}{l}-1+0.25 \mathrm{~mm}(\mathrm{TBS}) \\
-0.25 \mathrm{~mm} \text { (Flotation) }\end{array}$ \\
\hline Patherdih & 5.0 MTY & $\begin{array}{l}-75+13 \mathrm{~mm} \\
(\mathrm{Jig})\end{array}$ & $\begin{array}{l}-13+0.5 \mathrm{~mm} \\
(\mathrm{HM} \text { Cyclone })\end{array}$ & $\begin{array}{l}-0.5 \mathrm{~mm} \\
\text { (Flotation) }\end{array}$ \\
\hline Dahibari & 1.6 MTY & $\begin{array}{l}-50+13 \mathrm{~mm} \\
(\text { Deshaling Jig) }\end{array}$ & $\begin{array}{l}-13+0.5 \mathrm{~mm} \\
\text { (HM Cyclone) }\end{array}$ & $\begin{array}{l}-0.5 \mathrm{~mm} \\
\text { (WO Cyclone and Spirals) }\end{array}$ \\
\hline Patherdih & $2.5 \mathrm{MTY}$ & Not yet finalized & & \\
\hline Dugda & $2.5 \mathrm{MTY}$ & & & \\
\hline Bhojudih & $2.0 \mathrm{MTY}$ & & & \\
\hline
\end{tabular}

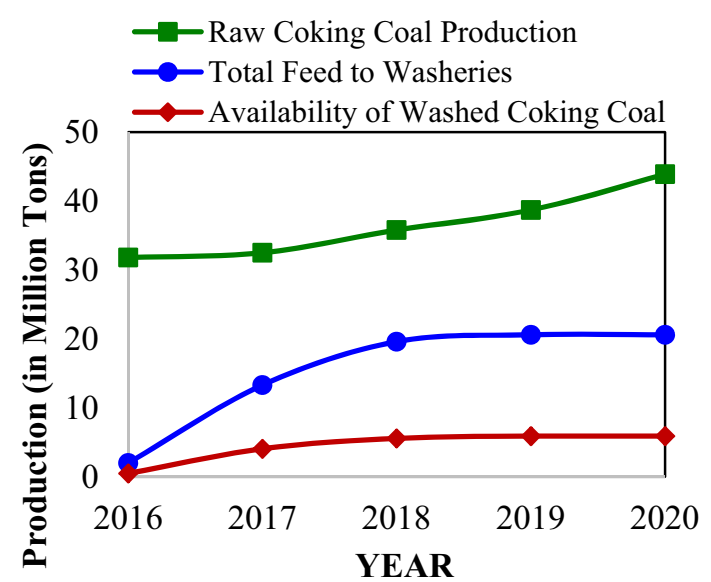

Fig. 2 Projection of Coking Coal Production in BCCL and washed coal availability to steel sector

However, operating a coal washery with such small coal size is not feasible under present techno-economics. This makes Indian Coal difficult to wash, resulting in poor yield and low organic efficiency.

Indian industries find Indian Coal inferior to the imported coal mainly because of high ash content. However, Indian Coal can also be characterized by low sulfur $(0.2 \%-0.7 \%)$, low iron, low chlorine, low toxic/rare earth elements content and macerals rich coal with high ash fusion temperature, and refractory nature of silica and alumina rich ash. It offers great potential for further investigation into coal washing technology dedicated for Indian Coal.

\section{Future of coal washing industry}

Government of India planned to expand coal-washing capacity in India by 13th Five Year Plan. Installation of 20 Coal Washeries in public sector with total installed capacity of 111.10 MT was envisaged. At present, CIL has taken up installation of 15 coal washeries on build, operate and maintain (BOM) Scheme.

Out of these, six are coking coal washeries, under the ownership of Bharat Coking Coal Limited with total design capacity of 18.6 MTY; and the remaining nine Washeries are Non-Coking Coal Washeries with total designed capacity of 74.5 MTY under the ownership of CCL (03 No-19.5 MTY), SECL (02 No-15 MTY) and MCL (04 No-40 MTY) subsidiaries of Coal India Limited (Saxena 2015; Sarkar et al. 2015).

The six coking coal washeries of Bharat Coking Coal Limited will be equipped with advanced automation and control circuits. Three of these washeries are under construction with the remaining under various stages of finalization. Typical cyclone-Cyclone, Jig-Cyclone combination has been used. deshaling cyclone and teeter bed separator (TBS) are being used for the first time in India.

A brief description of washing technology proposed in these washeries is presented in Table 5 (Sarkar et al. 2015; Sapru 2015).

These new washeries have been facilitated with rewashing circuit for the middling produced in their primary circuit; and $\mathrm{MoU}$ has already been signed for utilization of rejects produced in these washeries in FBC Power Plants and allied industries (Minutes of IMC Meeting).

With the allocation of new coal blocks for captive usage, new coal washeries in private sector are expected. S\&T Mining, a joint venture between Steel Authority of India Limited (SAIL) and Tata Steel Limited has been formed to look into the Mining and Coal Preparation activities of the newly acquired coal blocks to meet the demand of coking coal for their steel plants. Moreover, some American, European, South African and Asian Companies have formed consortiums with Indian Industries to invest in the coal washing sector in India. 
With installation of upcoming coal washeries in BCCL, total designed capacity of coking coal washeries in India will be 55.77 MTY by 2020 (Ministry of Coal 2014; Chakraborty et al. 2015; Saxena 2015; Sarkar et al. 2015). The projected production of Coal in BCCL and coal washing targets have been presented in Fig. 2 (Sarkar et al. 2015).

As evident from Table 4 and Fig. 2, present capacity utilization of existing washeries of BCCL is around $20 \%$. Study is being carried out by the authors for improving techno-economic performance of the washeries. Once the coal washing becomes a profitable proposition, BCCL management will be encouraged to revive the existing washeries for maximum capacity utilization with the objective of washing entire coking coal produced in BCCL. The other companies are expected to follow this and thus ensure utilization of Indigenous Coking Coal with no or substantial reduction in import.

\section{Scope for research and development}

As evident from Table 4 and Table 5, with deteriorating quality of coal, the complexity of washing would increase, and operators would resort to 4-5 stages of washing. Outcomes of several experiments carried out on Indian Coal and South African Coal (also of Gondwana Origin) reveal that separate washing of different size fractions have resulted in higher yield (Sapru 2015); and by integrating advanced process control, BATAC Jigs can be utilized to wash difficult-to-wash coal (Mustafi and Nandy 2015). Japan Coal has demonstrated the capability of Variwave Jigs in effectively washing Indian Coal (Koyanagi et al. 2015). FLSmidth has carried out several experiments on Indian Coal and have arrived to a conclusion that washing $-13+1 \mathrm{~mm}$ fraction in Heavy Media Cyclone, $-1+0.106 \mathrm{~mm}$ fraction in spiral concentrator and $-0.106 \mathrm{~mm}$ fraction in flotation cells will yield better results compared to $-13+0.5 \mathrm{~mm}$ in $\mathrm{HM}$ Cyclone and $-0.5 \mathrm{~mm}$ by Flotation (Moorhead and Woodruff 2015), which is a regular practice in India. Multotech Process Equipment, SA has conducted several tests on Indian Coal for beneficiation using spiral concentrator; and the results are encouraging (Smith and Erasmus 2015). Dr. Gouricharan, of CIMFR, Dhanbad has patented a novel washing scheme for LVMC Coal by adopting multi-stage, multi-stream coal washing circuit (Gouricharan 2015). However, the complexity of the operation and challenges of maintenance will increase and is likely to pose challenges in smooth operation and maintenance of the plant.

This implies that, there is scope for concerted R\&D efforts to find out relatively simpler washing scheme with maximum 2-3 stage of washing, which would not only simplify the operation and maintenance, but also overcome the shortcomings of existing 2-3 stage washing circuits.
There lies scope for comparative study of Indian Coal with Gondwana Coal from other countries in the southern hemisphere. So far, studies have shown that Indian Coal differs significantly from carboniferous coal found in northern hemisphere. However, there is hardly any literature on comparative study of Indian and South African or Australian Coal. This is the reason, coal washing technology used in these countries are accepted as suitable for Indian Coal with little or no modification. Ample opportunity is there for the scientific community to develop indigenous technology designed for difficult washing characteristics of Indian Coal.

Academic \& Research institution and technology providers should work in tandem with the industry, as they are ultimately responsible for implementing these technologies. Even after 60 years of Independence, Indian coal washing industry is at its nascent stage. This calls for a Academia-Research Institution and industry consortium to develop new and alternate process routes which are technically easier and superior, environmentally benign and economically sustainable.

\section{Conclusions}

The existing situation of Indian coal washing Industry is a resultant of gross negligence of the industries to strengthen R\&D for development of indigenous technologies. The Industry has relied from the very beginning on imported technology and machinery, ignoring the fact that foreign technologies have been developed taking into account the nature of coal in those countries, which is significantly different from that of Indian Coal, which possess difficult washability characteristics because of its drift origin. Neither the industry nor the government agencies have sponsored an exhaustive R\&D project dedicated to coal, despite it being the primary source of energy and infrastructural element in India.

Due to non-availability of such research facilities either at Govt. Research laboratories or Academic Institutions, Indian Scientific community has not yet been able to develop a cause-effect-solution matrix for operational and maintenance practices of Coal Washing Industry. It's one of the principal reasons behind existing condition of public sector Coal Washeries that were installed using imported technology but no indigenous intelligentsia to deal with regular operational and maintenance challenges. Had the academia-industry and research institution been working in tandem, the coal washing scenario in India would have been different.

Thus, attractiveness of Coal Washing Industry in India is high, but also full of challenges. PESTEL analysis of coal washing industry suggests that India is heading towards 
mandatory coal washing before end utilization. The deteriorating quality of raw coking coal poses challenges before the scientific community and the industry to find out simple and economically viable coal washing scheme for maximum recovery of coking coal for usage in metallurgical sector. There also lies scope for analyzing present condition of existing washeries, especially in public sector, to look for innovative techniques for revival of these washeries.

Open Access This article is distributed under the terms of the Creative Commons Attribution 4.0 International License (http://crea tivecommons.org/licenses/by/4.0/), which permits unrestricted use, distribution, and reproduction in any medium, provided you give appropriate credit to the original author(s) and the source, provide a link to the Creative Commons license, and indicate if changes were made.

\section{References}

Agrawal GC (1976) Public Sector Steel Industry in India, p 76 AICC (1965) Indian National Congress. Year of Freedom, vol 19

Alam M, Patel JP (2012) Coal washing in BCCL. In: Proceeding of Xstrata-ISM Flotation Workshop, Kolkata, India

CCL (Central Coal Fields Limited) History (2015) http://www.ccl. gov.in/comp/our_history.htm. Accessed 20 Oct 2015

CEMPDIL report (2016) Coal mining in India: history and perspective.

Chakraborty DP, Sen S, Ray PR, Kumar A , Tata Steel Limited (2015), Augmenting supplies of metallurgical coal to steel mills by upgrading low and medium coking coals, CPSI J, 2015, 66-72

CIL (Coal India Limited) History (2015) http://www.coalindia.in/enus/company/history.aspx. Accessed 20 Oct 2015

CMPDI (2015) Completed Projects (120 TPH Modular Washery at Lodna in 1992), Coal beneficiation section in http://scienceand tech.cmpdi.co.in/institution.htm. Accessed 20 Oct 2015

CCL (2012) Environmental statement, Kargali Washery, Central Coalfields Limited, 2012-2013

Das M (1975) Fantasy of coal nationalization, p 53

Ghosh AB (1964) The economics of coal washing in India, pp. 35-36

Gouricharan T (2015) Indian coal characteristics-emerging cost effective washing options. CPSI J, pp 125-130

Hindustan Steel Limited (1966) Statistics for Iron and Steel Industry in India, p 173

Konar BB, Banerjee SB, Choudhury SG, Das NS , Sen K (1998) Coal preparation: CFRI golden jubilee monograph, 1998, pp. 23-24

Koyanagi N, Endo H, Kubo Y, JCOAL and NECO (2015) Variwave jig in India, CPSI J, pp 140-144
Ministry of Coal (2015) Coal Reserves in India, http://coal.nic.in/ content/coal-reserves. 20 Oct 2015

Ministry of Coal (2012) Govt. of India, Coal washeries section in http://www.coal.nic.in. Accessed 2012

Ministry of Coal (2014) Govt. of India, Minutes of IMC meeting to review the issues related to formulation of policy on coal rejects allocation for washery rejects based power plants held on 08 Oct 2014

Ministry of Coal (2014) Govt. of India, Provisional coal statistics 2014-2015

Moorhead RG, Woodruff D, Smidth FL (2015) Evaluation of various HMC cleaning strategies to maximize yield of Indian coals, the coal beneficiation 2015 conference, April 2015, pp 79-88

Mustafi G, Nandy M (2015) MBE Coal and Mineral Technology India Pvt. Ltd., beneficiation of coal with under-pulsated jigs-is there anything new happening?. CPSI J, 158-164

NSO (2015), Ministry of Statistics and Program Implementation, Govt. of India, energy statistics 2015

Office of the Chief Economist (2015), Department of Industry and Science, Government of Australia, Coal in India.

Rai B, Tiwari R (2009) Coking coals: availability, quality, and beneficiation, proceeding of international conference on coking coals and coke making: challenges and opportunities, January 2009, Ranchi, India

Sapru HL (2015) Beneficiation of low volatile medium coking NLW coal in India. CPSI J, April 2015, pp. 55-65, Brief Presentation.

Sarkar A, Dutta SK, Patel JP ,Bharat Coking Coal Limited (2015) Augmenting demand of metallurgical coal for Steel Industry: challenges and opportunities, Brief Presentation, the coal beneficiation 2015 conference, April 2015

Sarkar GG, Ash PN, Rao SRR (1972) Studies on coal preparation in India, CFRI

Saxena BK (2015) Coal India Limited Brief Presentation, CPSI J, Coal Quality related Challenges and CIL's Plan of Action $145-157$

Sen K (2015) History of coal washing in India. http://www.kalyansen. com/Coal-preparation-in-India-historica-perspective.html. Accessed 20 Oct 2015

Singh VB, Guha B (1965) The Coal Mining Industry chapter in economic history of India. Allied Publishers, Chennai, pp 322-323

Sinha S (1988) Regional structure, processes, and patterns of development: a case study of Chhota Nagpur Region. Concept Publishing Company, New Delhi, p 74

Smith IGT, Erasmus WRJ (2015) Utilization of Spirals when Washing Coal, CPSI J, Multotec Process Equipment, SA, $170-176$

Tata Steel Limited(2015) Environmental statement for Jamadoba, Bhelatand, West Bokaro - II and West Bokaro - III coal washeries. http://www.tatasteelindia.com/environment-statement.asp. Accessed 20 Oct 2015 